\title{
State of Democracy in Sri Lanka: A Preliminary Report
}

\section{Jayadeva Uyangoda Pradeep Peiris}

\section{Introduction}

This paper is a preliminary report on citizens' understanding and perceptions of democracy in Sri Lanka, as reflected in a survey carried out in 2004-2005. The survey was a part of a South Asian study covering Bangladesh, India, Nepal, Pakistan and Sri Lanka on the theme "State of Democracy and Human Security in South Asia." The report of the overall study has now been published as State of Democracy in South Asia: A Report (2008).

In terms of methodology, the Study had four methodological 'pathways'. They are (i) case studies, (ii) dialogues, (iii) qualitative assessments, and (iv) cross- section surveys. The cross section survey carried out in each country was the principal instrument of data collection for the study. It sought to elicit broad trends of people's opinions, attitudes and behaviour in relation to democracy. The other three pathways provided qualitative assessments and dimensions that were not captured in the cross-section survey. The pathway of 'Dialogues' was chosen in order to recognise and retrieve bodies and voices of critical knowledge that are available among different social and political constituencies. Under the component 'Qualitative Assessments,' scholars active in social science research were asked to 'assess' the experience of democracy in a non-partisan basis. The qualitative assessments addressed questions formulated around five key themes: (i) the promise of democracy, (ii) design of democracy, (iii) working of democracy, (iv) democracy's outcomes, and (v) democracy's futures. 
This essay has two components. In the first, a brief account is given on the general observations and conclusions of the overall South Asian study as presented in the published Report (SDSA Report:2008). This account provides a broad context for the main findings of the crosssection survey in Sri Lanka. In presenting this brief South Asian account, we use the formulations of the Report with minor paraphrasing and alterations, without marking them as quotations. In the second part, some key findings from Sri Lanka's cross-section survey are presented. These observations are organised in the following thematic framework: meaning of democracy, alternatives to democracy, satisfaction with democracy and efficacy of democracy. In this paper, we present only broad generalisations that constitute a general picture of Sri Lankan citizens' encounters, perceptions and assessments of democracy. We intend to further explore these findings in depth in future, linking them to the findings of the qualitative components of the overall study.

\section{Part I}

\section{South Asia Report: Key ideas}

In the Report of the overall study published in 2008, "seven big ideas" were highlighted (SDSA Report 2008:6-7). The following is a summary of them.

(i). The idea of democracy has transformed South Asia as much as South Asia has transformed the idea of democracy. On one hand, the language, the practice and the institutions of democracy have transformed the popular common sense, everyday practices and relations of power. On the other hand, South Asia has re-worked the idea of democracy by infusing it with meanings that spill over the received frame of the idea of democracy.

(ii). South Asia disproves the notion that democracy cannot be instituted in conditions of mass poverty and illiteracy. It also goes against the expectation that democracy can be trusted to deliver development, security or human dignity.

(iii). Politics is central to the present and future of democracy in the region. Political organisations, that is, political parties as well as non-party political formations, continue to attract high degree of popular interest and involvement. They have the capacity not only to shape partisan loyalties and ideologies, but also social identities and economic interest.

(iv). People' orientations to democracy are shaped principally by political experience, rather than by their inherited identities. For example, religion by itself matters much less than the national political context 
in determining people's orientation to democracy, security and wellbeing. Political learning, by way of formal education, media exposure and experience of democracy, matters much more than any other factor in enhancing support for, trust in, and satisfaction with democracy.

(v). The strength of the practice of democracy in South Asia lies in its capacity to move away from the received model of democracy. These disjunctures are not a source of slippage or failure, distortion or deviation, but a source of innovation.

(vi). The encounter between South Asian cultures of democracy and the largely imported institutions has resulted in a bifurcation of institutions. For example, there are institutions that meet all the formal requirements of democracy, but lack in substance and vibrancy. On the other hand, there are institutions that connect with the people better, but have no formal democratic sanctity. Linkages between these two dimensions hold the key to the successful working of democracy.

(vii). There is a mismatch between 'subjective' and seemingly 'objective' dimensions of the working of democracy in South Asia. People's selfunderstanding in relation to democracy does not match their class ranking. Similarly, popular perceptions do not fit in with 'objective' economic data or expert perceptions, or even activist assessments of democratic experience and institutions. This interplay between subjective and objective dimensions, and of lay (popular) and expert view, is an important element in democratic politics. It allows space for democratic negotiation as well as subversion.

\section{Democracy Survey: Major observations}

In the analysis of the South Asia wide democracy study, the Report presents its key observations under eleven major themes. A summary of them under eight thematic headings is given below:

Aspiration for democracy: The support for democracy is fairly widespread across south Asia while very few doubt the suitability of democracy for their own country. Democracy is preferred over dictatorship everywhere except Pakistan. Meanwhile, affirmation of representative democracy is more widespread in South Asia than the negation of its alternatives. In terms of people's commitment to democracy, 'strong' and 'weak' democrats together outnumber the 'non-democrats.' At the same time, the support for democratic government is linked to the people's experience with democracy, exposure to democracy and education. Interestingly, education and economic position are significant in the support for democracy in South Asia. The higher the education, the higher is the support for democracy. South Asian elites are more firm in supporting democracy than the masses. There is also a noticeable gender 
gap in the support for democracy. More men are supporters of democracy than women. Among the strong supporters of democracy in South Asia are ethnic minorities, despite the general view that ethnic minorities are yet to benefit from democracy. In Sri Lanka, Pakistan and Bangladesh, ethnic minorities are more supportive of democracy than the majority. In India and Nepal, the minority-majority divide does not matter in supporting democracy.

Meanings of democracy: South Asians seem to have grafted onto the global ideal of democracy their own meanings. In South Asia, there is a greater emphasis on the substantive promise of democracy than some of the procedural aspects of democracy that are so central to the Western, liberal conception. The idea of democracy traveled to South Asia from Europe. Irrespective of the route through which it traveled, the idea of democracy in South Asia has over time become a part of the political commonsense. The vocabulary of democracy is routinely used for evaluating and critiquing political leadership. Though initially confined to a tiny English-speaking elite in all the South Asian countries, the cultures of democracy have since spread, though unevenly, to the mass publics. Thus, an imported concept of democracy has been adapted and assimilated into the cultures of democracy in South Asia.

It is against this backdrop that the meaning of democracy has been re-worked in South Asia. Among the multiple meanings people attribute to democracy, as revealed in the Survey are freedom, justice and welfare, popular rule, elections and political parties, peace and security, and the rule of law. Among the most essential attributes of democracy, the majority of South Asians give priority to the capacity of the polity to provide the basic necessities. The two most essential attributes of democracy, as preferred by $76 \%$ of South Asians, are basic necessities and equal rights. Compared with Africa and East Asia, the South Asian meaning of democracy puts more emphasis on equality and justice. People also have anxieties about democracy. Corruption is the principal anxiety, and the most disliked aspect of democracy for the South Asian citizens.

From design to promise: The various constitutional designs that embody the South Asian idea of democracy in different countries in the region reflect a rupture between the promise and design of democracy. In fact, the constitutional designs do not fully embody the promise of democracy. For example, even where equal citizenship rights are available in theory and law, they cannot be enjoyed in full measure. In all countries, constitutional provisions for accountability and autonomy have suffered erosion. Similarly, centralisation is the norm, despite the presence of decentralising and federal provisions. Government organs across the board are largely immune to public scrutiny and accountability.

Institutions and people: A major conclusion of the Study is that although the democratic institutions enjoy formal sanction in South Asia, this by itself has failed to ensure that they have come to develop deep roots in society. One implication of this conclusion is that representative 
institutions have not only suffered from an erosion of autonomy, but also enjoy a low level of popular trust. This has left the space for nonrepresentative institutions to engage in significant decision-making relating to governance. There is also an important paradox generated in this process. When these 'non-representative' institutions have successfully guarded and asserted their autonomy, they have tended to become less accountable to the people and are seen as reflecting elite interests.

To what extent do people trust institutions of governance? In the broad South Asian context, institutions are a weak link in the democratic chain. Institutions also face serious criticism, but not all institutions enjoy low public trust. Yet, democratic institutions have managed to earn popular trust. The picture in South Asia is one of modestly robust trust in institutions. There are country variations. Pakistan records the lowest trust in political institutions while Bangladesh has the highest. Meanwhile, religious and ethnic minorities are low on trust in institutions in both Bangladesh and Sri Lanka.

Party political competition: Political parties continue to be central to the political landscape of South Asia. They also reflect and give expression to the high degree of societal diversity - religious, linguistic, ethnic - and extreme disparities between individuals and groups. Reflecting these tensions, political parties have also assumed the character of coalitions. There is also a growing dissatisfaction with, and a lowering of trust in, the functioning of political parties. This has led to a paradoxical situation. People feel that the political parties are essential for the functioning of democracy, but do not seem to trust them for making democracy work. This lack of trust is paralleled with the fact that political parties have become election and patronage machines. The Survey enables two observations in this regard. Firstly, non-representative democratic institutions such as the Election Commission and the judiciary enjoy a higher public trust than political parties that are supposed to be representative institutions. Secondly, despite their lack of trust in them, South Asian citizens maintain a fairly high record of voting for the political parties at elections.

Democracy beyond parties and elections: Dissatisfaction with electoral politics in South Asia has led to a search for new forms of civic activism. This non-party political process is both complementary to, and in contention with, the electoral political process. It has helped expand and deepen democracy. Paralleled to non-party forms of political activism is the growing salience of religious and militant mobilisations. They also reflect deep infirmities with the formal institutions of politics and governance.

Political outcomes: The working of democracy in South Asia has resulted in more hope-generating 'intangible' political outcomes. The institutions of democracy have helped to empower former subjects into becoming fuller citizens, even though the substance of citizenship remains subject to contestation. The idea of democracy has introduced to South Asia the modern language of rights and helped provide an inclusive and dignified space to hitherto excluded groups. In short, it has reshaped the normative 
visions of people. At the same time, even as the practice of democracy has equipped citizens with new yardsticks of critical judgment, its failure to live up to its own standards remains a source of disappointment. The inability to protect minority rights is one big failure of democracy in South Asia.

Futures: Far from being a secure possession, the quest for democracy is an on-going struggle. Thus, the Report identifies three key challenges to democracy in South Asia: foundational challenges, challenges of expansion, and challenges of deepening. The future of the democratic enterprise of each South Asian country is intimately linked to the larger trajectories of social change and political transformation that are not confined within national borders.

\section{Part II}

\section{Sri Lanka Study: Background}

In the Sri Lanka country study too, the methodology of four pathways was followed. There were three 'Case Studies' done in Sri Lanka. They are on (i) "Democracy, power and violence," (ii) family and politics, and (iii) youth and democracy's future. Themes of the case studies were chosen to explore some of the key paradoxes, or 'inconvenient truths', about the experience of democracy in each country. The Sri Lankan study had three 'democracy dialogues' to which political and social activists, students, trade union organisers, women activists and intellectuals were invited. Themes of the three democracy dialogues were "state of democracy in Sri Lanka," "democracy: majorities and minorities," and "democracy and human security." The qualitative assessments addressed questions formulated around five key themes: (i). the promise of democracy, (ii), design of democracy, (iii) working of democracy, (iv) democracy's outcomes, and (v) democracy's futures.

The cross-section survey was conducted in the late 2004 and early 2005 in 75 out of 196 parliamentary constituencies in the country, covering all the nine provinces and 21 administrative districts. The number of constituencies per district was decided on the proportion of the population and the socio- political diversity of each district. In the Northern and Eastern Provinces, the survey was conducted only in the areas that at the time were under government control. Further, constituencies in the northern and eastern provinces were over-sampled in order to facilitate detailed analysis at the district level and within ethnic communities. A total of 6 polling booths were chosen from each selected constituency using the Simple Random Sampling (SRS) technique. The latest voter lists were used as the sampling frame to select the respondents within a polling station and the selection was done using the SRS technique. A total of 4600 interviews were conducted in 21 districts across the country while within each polling booth a total of 15 people were interviewed by the field researchers. 


\section{Studying and reporting on democracy in Sri Lanka}

Sri Lanka's democracy offers a specific problematic. The country has a relatively long encounter with institutions and practices of liberal democracy. The universal franchise as well as partially representative government was established in Sri Lanka as far back as 1931, when the island was still under the British colonial rule. Sri Lanka's institutions of electoral and parliamentary democracy continue to exist with only minor deviations along with a continuing civil war and amidst violence. Sri Lanka has not had successful attempts at extra-parliamentary rule. The only military coup attempt was made in 1962, but it could not take off the ground beyond the planning stage. This has led some commentators to argue that despite minor deviations, Sri Lanka's democratic governance has been "resilient" (de Silva: 1998). However, as the political change in recent decades indicates, 'democratic resilience' does not capture the whole story of the post-colonial political change in Sri Lanka. There are at least two parallel developments along with the apparent institutionalisation and consolidation of parliamentary and electoral democracy. The first is what some scholars have described in such terms as "institutional decay," "political decay," "illiberal democracy," "retreat from democracy" and "constitutional authoritarianism."

The second parallel level of politics is that of the armed insurgency, rebellion, counter-insurgency warfare and violence. Since the early 1970s, politics in Sri Lanka has been taking place at two levels -- first at the level of legal, electoral and parliamentary practices and second, as counter-state mobilisation, armed rebellion and counter-insurgency war. Institutions of parliamentary democracy appear to have taken firm roots in the Sri Lankan society, as characterised by a comparatively long institutional history of modern democracy, high level of electoral participation, penetration of the political party system into all corners of the society, and the regular and peaceful change of regimes by means of elections. However, Sri Lanka has also produced twin counter-state insurgencies - one in the majority Sinhalese society and the other in the minority Tamil society. The concentration of the civil war process since the 1970s demonstrates a particular co-existence between two seemingly contradictory processes, parliamentary democracy and anti-state rebellions. The prevalence of counter-state insurgencies indicates that Sri Lanka's democracy has had some serious limitations in addressing the substantial social and ethnic grievances. But, these systemic challenges do not yet seem to have precipitated any serious democracy reform endeavor. Sri Lanka's democratic paradox is further highlighted by the remarkable resilience of state institutions to stay unreformed despite four decades of rebellion, protest and political violence. Counter-state armed rebellions have not led to political structural reforms, but to a culture of 'reform resistance' (Uyangoda: 2000) 
During the period in which the Survey was carried out, late 2004 and early 2005, Sri Lanka had a backdrop of some significant political developments. Key among them was the suspension of the internationally mediated peace negotiations between the government and the Liberation Tigers of Tamil Eelam (LTTE). The peace talks, backed by a cease-fire agreement between the government and the LTTE, intended to manage Sri Lanka's civil war by means of a mutually acceptable political settlement. After six rounds of talks, the peace process that began in early 2002 came to a halt in early 2003. All attempts made by the international backers of the peace process to resume the talks had failed. However, the cease-fire agreement monitored by a Nordic group of observers continued to hold preventing any early relapse to full-scale war. There was also a regime change occurred at the parliamentary elections held April in 2004, when the opposition United People's Freedom Alliance (UPFA) won the majority of parliamentary seats. The UPFA replaced the United National Front (UNF) government which had been engaging in a peace process with the LTTE. In political and ideological terms, the new UPFA regime represented a Sinhalese nationalist coalition that was hostile to the internationallybacked political engagement between the UNF government and the LTTE.

The Tsunami of 2004 occurred during the period of this study. The Tsunami was politically significant in the sense that it opened up a new humanitarian window of opportunity for the new UPFA government and the LTTE to return to the negotiation table. In early 2005, the two sides established contacts and began negotiating a framework text for a joint post-tsunami reconstruction mechanism called Post-Tsunami Operational Management Structure (P-Toms). When in July 2005 the government and LTTE representatives signed a Memorandum of Understanding (MoU) in order to set up this joint administrative structure, Sinhalese nationalist elements in the government challenged its constitutional validity before the Supreme Court. The Court in its judgment delivered in September 2005 invalidated the P-TOMS. This development was symptomatic of the intensity of the ethnic-nationalist atmosphere that existed during the period in which the cross-section survey was carried out in Sri Lanka.

The political economy context that existed in Sri Lanka during 20042005 also had some significant dimensions. Sri Lanka began economic liberalisation in 1977-1978, and was the first South Asian country to move in the direction of free-market centric macro-economic reforms. In the late 1980s, Sri Lanka also began to implement Structural Adjustment Programmes, thereby completing the agenda of economic liberalisation. Even the nationalist-Left coalition government that came to power in 1994 and was in office till the end of 2001 did not alter the basic framework of the liberalised economy. During the UNF-led peace process with the LTTE, there was a new policy emphasis on greater internationalisation of the Sri Lankan economy. In fact, the UNF government appeared to think that the consequences of rapid economic growth, facilitated by economic incentives of peace and greater involvement of foreign capital and donor 
assistance, would eventually weaken, and even make irrelevant, the militant Tamil project for secession. However, the UNF government's project of internalisation of both the peace process and economic development politically backfired. This background facilitated the emergence of a significant social and political discontent towards the liberal economy. The new UPFA regime of 2004 to some extent embodied demands for returning to some measure of social welfarism and state involvement in protecting the vulnerable social groups, particularly the rural peasantry.

To return to Sri Lanka's democracy problematic noted above, Sri Lanka can in a way be considered as an 'old democracy.' It has wellestablished institutions of democratic governance, yet many of them do not seem to have the energy and vitality required for the deepening of democracy or constructively grappling with the country's ethno-political civil war. The fact that the governments have often resorted to nonpolitical institutions - primarily the military - to deal with the ethnic conflict as well as social discontent and that the state structures remain stubbornly unreformed reflect how Sri Lankan democracy has assumed a conservative, or somewhat 'aged', character. The actually existing democracy is the status quo that refuses to re-invigorate itself. Do citizens evaluate democracy in these terms, in a similar sense of disenchantment, often expressed in democracy dialogues and the qualitative assessments? Does the Survey tell the political critic and the activist that the vitality of democracy is not yet lost? The discussion in the following section will provide answers to these and similar questions.

\section{Democracy and Sri Lankan Citizens}

\section{Understanding of Democracy}

The Survey attempted to build a picture of how the citizens in Sri Lanka understood and related themselves to democracy. With that objective in mind, the Survey focused on the meanings, characteristics and attributes of democracy as people understood it. The following are some of the key findings in relation to Sri Lanka. ${ }^{2}$

(i). Meaning of democracy: People obviously understand democracy in a variety of ways. For the majority of Sri Lankan citizens, the two most important meanings of democracy are freedom (54\%) and justice (28\%). Popular rule, elections and the rule of law are of low priority as meanings of democracy. This understanding of democracy primarily as freedom and justice is shared almost equally by the rural as well as urban citizens and both men and women. In terms of social position too, whether elite or non-elite, this understanding of democracy remains without a significant change. The only interesting change in the way democracy is understood is observable when ethnic minority communities attached a significant value to 'peace and security' as meanings of democracy. Over one third of NorthEast Tamils and Up-Country Tamils -37 and 36 percents respectively - 
and over one-fourth of Muslims considered peace and security as important meanings of democracy as were freedom and justice.

Another way in which the Survey attempted to understand how people relate themselves to democracy was to find out what essential characteristics they attributed to democracy. Forty percent of Sri Lankans consider equal rights to be the "most essential element of democracy." In fact, Sri Lankans consider equal rights, opportunity to change the government (19 \%) and availability of basic necessities to all (17\%) as democracy's three most essential elements. Free speech and action ("everyone is free to speak and act") is the attribute of democracy which most Sri Lankans, $54 \%$, like. Other attributes have much less support. For example, only $13 \%$ consider "people have control over their rulers" as the most liked attribute of democracy. The proposition that "interests of minorities are protected" has only $12 \%$ support, but it is still higher than the South Asian average of $6 \%$. The statement that "democracy treats the weak with dignity" is seen as the most liked attribute of democracy in Bangladesh with 54\% support, while among Sri Lankans it has only $7 \%$ support. These country variations reflect the social conditions as well diverse aspirations that shape how citizens relate themselves to democracy.

What is the most disliked attribute of democracy? Sri Lankan citizens seem to dislike three aspects of democracy: corruption, divisiveness and the 'tyranny of the numerical majority.' The largest group of respondents, $49 \%$, thinks that corruption increases under democracy. So do 35\% of all the South Asians. The second attribute of democracy which Sri Lankans dislike most is that democracy divides people with too many political parties. This reflects the negative assessment of the role of political parties. Sri Lanka's history of political parties is over sixty years. Political parties have penetrated all corners of society not only as agencies of democratic mobilisation and participation, but also institutions of localised power and domination, patron-client relations, political corruption and at times violence. Thus, this skeptical assessment of political parties demonstrates a critical reflection on the part of the citizens of their encounters with the institutions and agencies of democracy. They also reflect some deep anxieties about the existing democracy. Obviously, the popular support for democracy does not seem to be unconditional. Majoritarian democracy leading to tyranny of the numerical majority ("those who have more votes dominate over others") is seen by $12 \%$ as the most disliked aspect of democracy.

Sri Lanka's preference for representative democracy is quite high as it is the case with Bangladesh, India and Nepal. 43\% of Sri Lankans "strongly agree" and another 45\% "agree" with the statement that "the country should be governed by those chosen by the people in a fair election." The average South Asian figures are 48\% "strongly agree" and 29\% "agree." In the Sri Lankan case, the highest support for representative democracy comes from ethnic/religious minorities, the urban areas and male voters. 
(ii). Alternatives to Democracy: In assessing people's attitudes towards democracy, the Survey explored how the Sri Lankan citizens see the alternatives to democracy. To the proposition that 'dictatorship' is a preferable alternative to democratic rule, 53\% Sri Lankans said that democracy was preferable to dictatorship.' Only $9 \%$ have reported to prefer dictatorship over democracy. In the overall South Asian context, the percentage of Sri Lankans who prefer democracy is higher. The average South Asian figure is $42 \%$.

Meanwhile, the percentage of Sri Lankans who prefer dictatorship (9) is also slightly higher than the South Asian average of 7\%. Interestingly, Sri Lanka's preference for dictatorship equals Pakistan with 9\% preference in each country, although Sri Lankans had not experienced a dictatorial rule. The corresponding 'preference for dictatorship' figures for Bangladesh, India and Nepal are 6\% each. Meanwhile, 13\% Sri Lankans say that democracy or dictatorship makes no difference to them, while $25 \%$ had no opinion on this choice. There are two ways to interpret this data. On one hand, on the question of a choice between democracy and dictatorship, Sri Lankan data offers a somewhat unsettling picture. On the other hand, it is probably a minor desire for something the citizens had never directly encountered. The consolation for the well-wishers of Sri Lankan democracy is that Sri Lanka has the lowest figure for those for whom democracy or dictatorship makes no difference, In Pakistan, which has seen longsurviving military-authoritarian regimes, dictatorship makes no difference to $32 \%$ of people, which is the highest in South Asia. Even for India, the corresponding figure is slightly higher than for Sri Lanka (14\%).

Among the alternatives to democracy that the voters were asked to state their preference was monarchy, military rule and a system of governance where religious leaders make major decisions. Only a very small number of Sri Lankan preferred monarchy, with only 4\% 'strongly agreeing" and 17\% 'agreeing.' In Nepal where a monarchy had actually existed when this study was carried out, the support for monarchy was less than half, with $19 \%$ 'strongly agreeing' and 26\% 'agreeing.' Meanwhile, Sri Lanka showed more support for 'rule by strong leader.' Preference for strong leader was $62 \%$, which was higher than the average South Asian figure of $50 \%$. Sri Lanka's was the second highest preference for 'rule by strong leader' with Nepal recording almost similar preference with 63\%. However, Sri Lanka's preference for army rule and religious leaders was comparatively low. Only 23\% of Sri Lankans, compared with the South Asian average of $32 \%$, preferred the army rule. The percentage of Sri Lankans disagreed with the preference for army rule was 63\%, which was the highest in South Asia. This stood in sharp contrast with both Bangladesh and Pakistan where 50\% and $49 \%$ preferred the army rule. Sri Lanka's preference for 'religious leaders taking major decisions' was also low, with only $21 \%$ support, whereas those who disagreed with that proposition was as high as $57 \%$. The average South Asian support for religious leaders to take major policy decisions was also low with $17 \%$, with half of the South Asians, 50\% disagreeing. 
Sri Lanka's low preference for the proposition that 'religious leaders should take major decisions' has had a noteworthy contextual dimension. In 2004, during the latter part of which the cross-section survey was carried out, a new Sinhalese-Buddhist political party had stormed the electoral and parliamentary arena. Known as the Jathika Hela Urumaya (JHU National Heritage Party), this new political entity fielded over 200 Buddhist monks as candidates at the parliamentary election held in April 2004. Nine of them were elected as MPs. Their main message to the electorate had two key ideas: they were there as professional politicians and MPs to protect the interests of the Sinhalese-Buddhist majority community and they were committed to restoring the morality in public affairs. The campaign of the JHU on these two counts does not seem to have convinced the electorate in any major way. What it perhaps indicates is that the Sri Lankan electorate is essentially secular as is the South Asian electorate in general.

Meanwhile, the picture of the depth of support for democracy in Sri Lanka, as it is the case in South Asia, is somewhat complex one as reflected in the Survey. 'Strong' and 'weak' democrats together outnumber the 'non-democrats,' yet the overall picture for the support for democracy is a moderate one. The SDSA Report measured the support for democratic government in South Asia through a three-fold typology of 'strong democrats,' 'weak-democrats' and 'non-democrats.'

Strong Democrats are those who support democratic government by elected representatives while strongly rejecting non-democratic alternatives. Non-democrats are those who prefer dictatorship OR for whom democracy and dictatorship does not matter AND support the army rule or monarchy OR strongly reject the rule by elected representatives. Further, they accept unambiguous forms of non-democratic rule. The individuals who neither fall into the strong democrats nor non-democrats are defined as weak democrats or ambivalent democrats. Weak democrats do not fit into either of the above two categories. However, they are closer to democrats than to non-democrats.

Although this typology is based on a somewhat narrow definition of democracy - 'rule by elected representatives --, it still provides a useful glimpse into how committed the citizens are to democratic government as opposed to its alternatives. Sri Lanka's strong democrats are 36\%, weak democrats are 50\%, and non-democrats 14\%. An optimistic interpretation of this data is that among Sri Lankans, the share of 'strong democrats' is twice as mush as 'non-democrats.' The Sri Lankan figure of 'strong democrats' is higher than the corresponding figure for South Asia (26\%), although it is lower than Latin America (43\%). However, the cause for concern is the fact that half of the Sri Lankans falls into the category of 'weak democrats.' 3 


\section{Evaluating the Performance of Democracy}

\section{Satisfaction with democracy}

Asked to indicate how satisfied they were with the way democracy worked in the country, $42 \%$ of Sri Lankans recorded satisfaction, with $4 \%$ being 'very satisfied' and 38\% 'satisfied.' The corresponding South Asian overall figure differs only marginally, with 43 both 'very satisfied' and 'satisfied.' Somewhat paradoxically, the highest figures for the satisfaction with democracy were reported from Bangladesh where military rule had replaced democratic governments a number of times and democracy had not addressed many of the socio-economic problems. There, $21 \%$ were 'very satisfied' with democracy and 32 percent 'satisfied.'

As the following table indicates, the data on the satisfaction with democracy indicates interesting variations. The most surprising observation is that ethnic minorities show greater satisfaction with democracy. The Tamil and Muslim minority communities are more satisfied with democracy than the Sinhalese majority. The Up Country Tamil community has expressed the least satisfaction. ${ }^{4}$ The data on dissatisfaction with democracy shows another side of the satisfaction problematic. The highest among the dissatisfied with democracy are also Tamils. This outcome is quite understandable in the context of Sri Lanka's protracted ethnopolitical civil war and the Tamil grievance that they have not been given their due political rights. As we noted earlier in the paper, one of the greatest failures of democracy in South Asia is in the area of minority rights. An issue that warrants further inquiry and study is reflected in the anomaly that can be observed between the level of satisfaction (45.4\%) and dissatisfaction (37.3\%) with democracy among the Tamils in Sri Lanka. The question in this regard is about explaining why more Tamils, who have been at the receiving end of Sri Lanka's majoritarian democracy, are satisfied with democracy while a lesser percentage is dissatisfied.

Table 1. Satisfaction with democracy by ethnicity, age, gender, locality, and education.

\begin{tabular}{|l|l|l|l|l|l|}
\hline & SATISFIED & DISSATISFIED & NO OPINION & TOTAL \% & BASE (N) \\
\hline ETHNICITY & & & & & \\
\hline Sinhala & $42.3 \%$ & $35.4 \%$ & $22.3 \%$ & $100 \%$ & 3312 \\
\hline Tamil & $45.4 \%$ & $37.3 \%$ & $17.2 \%$ & $100 \%$ & 506 \\
\hline Muslim & $51.4 \%$ & $21 \%$ & $27 \%$ & $100 \%$ & 500 \\
\hline UC-Tamil & $38.2 \%$ & $23.5 \%$ & $38.2 \%$ & $100 \%$ & $\mathbf{1 5 7}$ \\
\hline AGE & & & & & \\
\hline $18-30$ & $49.5 \%$ & $37.1 \%$ & $13.5 \%$ & $100 \%$ & $\mathbf{1 0 7 1}$ \\
\hline $31-40$ & $45.8 \%$ & $34 \%$ & $20.2 \%$ & $100 \%$ & 839 \\
\hline $41-50$ & $43.8 \%$ & $33.1 \%$ & $23.1 \%$ & $100 \%$ & $\mathbf{7 8 1}$ \\
\hline
\end{tabular}




\begin{tabular}{|l|l|l|l|l|l|}
\hline $51-60$ & $41.7 \%$ & $33.6 \%$ & $24.7 \%$ & $100 \%$ & $\mathbf{6 0 8}$ \\
\hline $60+$ & $31.4 \%$ & $26.8 \%$ & $41.9 \%$ & $100 \%$ & $\mathbf{4 2 2}$ \\
\hline GENDER & & & & & \\
\hline Male & $44.9 \%$ & $40.2 \%$ & $15 \%$ & $100 \%$ & $\mathbf{2 1 2 0}$ \\
\hline Female & $42.5 \%$ & $27.5 \%$ & $29.8 \%$ & $100 \%$ & $\mathbf{2 4 9 6}$ \\
\hline LOCALITY & & & & & \\
\hline Rural & $42.9 \%$ & $33.1 \%$ & $24.0 \%$ & $100 \%$ & $\mathbf{4 0 2 8}$ \\
\hline Urban & $48.0 \%$ & $35.9 \%$ & $10.2 \%$ & $100 \%$ & $\mathbf{5 8 8}$ \\
\hline EDUCATION & & & & & \\
\hline Non-Literate & $17.0 \%$ & $10.5 \%$ & $72.5 \%$ & $100 \%$ & $\mathbf{2 2 9}$ \\
\hline Below Primary & $36.3 \%$ & $19.3 \%$ & $44.4 \%$ & $100 \%$ & 856 \\
\hline Below O/L & $48.0 \%$ & $35.6 \%$ & $16.4 \%$ & $100 \%$ & $\mathbf{2 7 3 7}$ \\
\hline O/L and A/L & $46.2 \%$ & $47.7 \%$ & $6.1 \%$ & $100 \%$ & $\mathbf{6 6 0}$ \\
\hline $\begin{array}{l}\text { Graduate and } \\
\text { above }\end{array}$ & $37.6 \%$ & $60.0 \%$ & $2.4 \%$ & $100 \%$ & 85 \\
\hline
\end{tabular}

Young Sri Lankans are more satisfied than dissatisfied with the way democracy has worked in the country. Interestingly, the satisfaction as well as the dissatisfaction figures gradually decline with older people. Similarly, the inability to make an opinion whether satisfied or not with the way democracy works in Sri Lanka also increases with age. The satisfaction with democracy does not differ significantly according to gender, yet the Survey shows that Sri Lankan men were more dissatisfied than women with democracy. Whether one lived in a rural area or urban area does not seem to influence the citizen's assessment of the way in which democracy has worked. But, there is a greater dissatisfaction with the working of democracy among the elites with higher levels of education and wealth.

Can citizens influence those who rule?

Most Sri Lankan citizens seem to believe that their vote does count in influencing those who rule the country. As the 'efficacy of democracy' table shows below, there are interesting variations in this regard in terms of ethnicity and education.

When asked whether their vote counted, a three fourth of the Up Country Tamil community and $70 \%$ of the Sinhalese community stated that their vote had an effect. However, minority Tamils and Muslims did not seem to believe that they could influence the regime through their ballot. The Tamils and Muslims who affirmed that their vote made a difference were less than fifty percent, a significantly low figure compared with the Sinhalese and Up Country Tamils. Close to one third of Tamil and Muslim citizens stated that their vote did not make any difference in the way politics worked in the country whereas the number of Sinhalese and Up Country Tamils who thought so was less than twenty percent. 
This variation in terms of the ethnic community on efficacy of democracy requires further analysis and study. A hypothesis worth examining in this regard is that a community's assessment of the efficacy of democracy is shaped by its relationship with the state.

Table 2. Efficacy of Democracy by Ethnicity, Age, Gender, Locality and Education

\begin{tabular}{|c|c|c|c|c|c|}
\hline & $\begin{array}{l}\text { MAKE NO } \\
\text { DIFFERENCE }\end{array}$ & HAS AN EFFECT & NO OPINION & TOTAL \% & BASE (N) \\
\hline \multicolumn{6}{|l|}{ ETHNICITY } \\
\hline Sinhala & $18.2 \%$ & $71.3 \%$ & $10.5 \%$ & $100 \%$ & 3312 \\
\hline Tamil & $31.2 \%$ & $48.4 \%$ & $20.4 \%$ & $100 \%$ & 506 \\
\hline Muslim & $33 \%$ & $51.8 \%$ & $15.2 \%$ & $100 \%$ & 500 \\
\hline UC-Tamil & $14 \%$ & $75.2 \%$ & $10.8 \%$ & $100 \%$ & 157 \\
\hline \multicolumn{6}{|l|}{ AGE } \\
\hline $18-30$ & $21.5 \%$ & $69.1 \%$ & $9.4 \%$ & $100 \%$ & 1071 \\
\hline $31-40$ & $22.5 \%$ & $66.7 \%$ & $10.8 \%$ & $100 \%$ & 839 \\
\hline $41-50$ & $18.9 \%$ & $71.4 \%$ & $9.7 \%$ & $100 \%$ & 781 \\
\hline $51-60$ & $20.4 \%$ & $67.6 \%$ & $12 \%$ & $100 \%$ & 608 \\
\hline $60+$ & $22 \%$ & $53.4 \%$ & $24.7 \%$ & $100 \%$ & 422 \\
\hline \multicolumn{6}{|l|}{ GENDER } \\
\hline Male & $19.2 \%$ & $72.5 \%$ & $8.3 \%$ & $100 \%$ & 2120 \\
\hline Female & $22.6 \%$ & $61.5 \%$ & $15.9 \%$ & $100 \%$ & 2496 \\
\hline \multicolumn{6}{|l|}{ LOCALITY } \\
\hline Rural & $19.9 \%$ & $67.7 \%$ & $12.4 \%$ & $100 \%$ & 4028 \\
\hline Urban & $29.3 \%$ & $58.5 \%$ & $12.2 \%$ & $100 \%$ & 588 \\
\hline \multicolumn{6}{|l|}{ EDUCATION } \\
\hline Non-Literate & $22.3 \%$ & $40.6 \%$ & $37.1 \%$ & $100 \%$ & 229 \\
\hline Below Primary & $23.5 \%$ & $58.3 \%$ & $18.2 \%$ & $100 \%$ & 856 \\
\hline Below O/L & $21.0 \%$ & $68.6 \%$ & $10.4 \%$ & $100 \%$ & 2737 \\
\hline $\mathrm{O} / \mathrm{L}$ and $\mathrm{A} / \mathrm{L}$ & $18.2 \%$ & $77.1 \%$ & $4.7 \%$ & $100 \%$ & 660 \\
\hline $\begin{array}{l}\text { Graduate and } \\
\text { above }\end{array}$ & $16.5 \%$ & $80.0 \%$ & $3.5 \%$ & $100 \%$ & 85 \\
\hline
\end{tabular}

Educational level seems to be another significant factor in determining the voters' belief in the efficacy of democracy. The table above supports the proposition that the higher the education level, the greater is the belief in the efficacy of democracy. Greater numbers of educated people who have passed Ordinary Levels, Advanced Levels, and university degrees than their less educated counterparts believed that their vote did matter. Meanwhile, an interesting point that emerges in a further analysis 
of the data is that there is no relationship between the satisfaction of the way democracy worked and the belief in the efficacy of democracy. It also suggests that satisfaction with democracy does not necessarily make a citizen a strong democrat. Strong democrats are satisfied with the way democracy worked in the country, but those who are satisfied with democracy are not automatically strong democrats. To be a strong democrat, one has to be more than a believer in the efficacy of democracy; one has to reject all the alternatives to democracy as well.

\section{Conclusions}

Going along with the general South Asian tendency, the Sri Lankan citizens seem to have appropriated the European, liberal conception of democracy with a greater emphasis in its meaning on the substantive, rather than procedural, dimensions. Freedom, justice and welfare, and peace and security are the three most important meanings which the vast majority of Sri Lankan respondents of the survey have indicted as the meaning of democracy. Procedural aspects of democracy are relevant, but not crucial to making sense of democracy for most of the people in Sri Lanka. In the overall South Asian regional picture, procedural dimensions have a greater salience than in Sri Lanka.

Those who claim to be the greatest supporters of democracy are the educated and elite sections of society. Citizens of the lower levels of educational and economic achievements seem to be both critical and open about what democracy has actually meant to them. So are the women. Men in Sri Lanka claim to be greater enthusiasts of democracy than women. The greatest skeptics of democracy in Sri Lanka, as indicated in the survey, are the older people, with greater exposure to democracy and its disappointments as well. When citizens grow older, they seem to develop a critical assessment of democracy whereas the young display a less critical approach.

Sri Lankans in general seem to be quite weary of the alternatives to democracy. There is very little support for non-democratic alternatives to the existing forms of democratic governance despite the infirmities of the latter. However, there is also cause for concern. Nearly a quarter of Sri Lankans prefer army rule and the most support for army rule comes from the Buddhists. There is also an overwhelming support in Sri Lanka for 'rule by strong leader,' despite Sri Lanka's experience since the 1980s of constitutional authoritarianism built around the powerful office of the President. On the question of the commitment to the rule by elected representatives, one-half of Sri Lankans are 'weak democrats.'

A first reading of the survey results does not suggest any major surprises about the attitudes and perceptions of Sri Lankan people's towards democracy. A detailed reading may indicate complexities, anomalies and nuances. Some questions that emerge from this broad account warrant deeper examination. For example, why is it that ethnic minorities show greater satisfaction with democracy when the Sri Lankan democracy has 
so far failed to address their political grievances? Why do more men than women appear to value democracy? Why do more young citizens than their older counterparts believe in the efficacy of democracy? Who are the 'weak democrats' and why are they 'weak democrats'? Is Sri Lankan democracy secular? We seek to examine these and similar questions in depth in another essay.

\section{Endnotes}

1 For the 'crisis' literature on Sri Lanka's recent politics see Manor: 1984, Tambiah: 1986, Moore: 1992, Coomaraswamy: 1996, Senaratne: 1997, Krishna: 1999, De Votta: 2002 and 2003.

2 All the survey data cited on Sri Lanka in this paper are from SDSA Report: 2008.

3 The notion of 'weak democrats' in Sri Lanka needs to be further explored in relation to both survey data and qualitative research. We intend to do so in our future work.

4 Up Country Tamils are a distinct minority community in Sri Lanka who differs from the Tamil community living elsewhere in Sri Lanka. As the name suggest, the Up Country Tamils live in the central Hill Country, primarily as workers in the tea plantations. They were brought to Sri Lanka by the British in the late $19^{\text {th }}$ and the early $20^{\text {th }}$ centuries from Southern India as indentured labour. After decades of struggle, almost all of them have now got citizenship rights, but they continue to live in poverty and marginalisation. However, they have representation in the Cabinet, national parliament and provincial and local bodies. 


\section{References}

Coomaraswamy, Radhika, 1996, Ideology and the Constitution: Essays on Constitutional Jurisprudence, Colombo: International Center for Ethnic Studies.

De Silva, K. M. 1998, "Sri Lanka: Electoral Politics and the Resilience of Democracy," in John m. Richardson Jr. and S. W. R. de a Samarasinghe, 1998, Democratisation in South Asia: The First Fifty Years, Kandy, Sri Lanka: International Center for Ethnic Studies, pp. 163-186.

DeVotta, Neil, 2002, "Illiberalism and Ethnic Conflict in Sri Lanka,' Journal of Democracy, Vol. 13, No. 1, pp. 84-98.

DeVotta, Neil, 2003, "Sri Lanka's Political Decay: Comparing the October 2000 and December 2001 Parliamentary Elections,' Commonwealth and Comparative Politics, Vol. 41, No. 2, pp. 115-142.

Krishna, Sankaran, 1999, Postcolonial Insecurities: India, Sri Lanka and the Question of Nationhood, Minneapolis and London: University of Minnesota Press.

Manor, James, (ed.), 1984, Sri Lanka: in Change and Crisis, London: Croom Helm.

Moore, Mick, 1992, "Retreat from Democracy in Sri Lanka," Journal of Commonwealth and Comparative Politics, No. 30, pp. 70-84.

SDSA, 2008, State of Democracy in South Asia: A Report, New Delhi: Oxford University Press.

Senaratne, J. P. S. 1997, Political Violence in Sri Lanka 1977-1990: Riots, Insurrections, Counterinsurgencies, Foreign Interventions, Amsterdam: VU University Press.

Tambiah, S. J. 1986, Sri Lanka: Ethnic Fratricide and Dismantling of Democracy, Delhi: Oxford University Press.

Uyangoda, Jayadeva, 2000, "A State of Desire? Some Reflections on the Unreformability of Sri Lanka's Post-colonial Polity," in Marcus Mayer and Siri Hettige (eds.), Sri Lanka at Crossroads: Dilemmas and Prospects after 50 Years of Independence, New Delhi: Macmillan, pp.92-118. 